\title{
PROFIL BERPIKIR MAHASISWA DALAM MEMECAHKAN MASALAH NUMERICAL ANALYSIS DITINJAU DARI TIPE KEPRIBADIAN
}

\author{
VERA DEWI SUSANTI \\ vera.mathedu@ikippgrimadiun.ac.id \\ SWASTI MAHARANI \\ swastimh@gmail.com \\ Program Studi Pendidikan Matematika \\ IKIP PGRI Madiun
}

\begin{abstract}
Abstrak. Penelitian ini bertujuan untuk mendeskripsikan profil berpikir mahasiswa tipe guardian, artisan, rational, dan idealist dalam memecahkan masalah numerical analysis. Jenis penelitian ini adalah deskriptif kualitatif. Subjek penelitian ini adalah mahasiswa pendidikan matematika semester VII IKIP PGRI Madiun. Pemilihan subjek penelitian berdasarkan teknik pengambilan stratified sampling dan purposive sampling. Hasil penelitian menunjukkan bahwa mahasiswa dengan tipe kepribadian Guardian, hanya melakukan proses asimilasi dalam memahami masalah dan membuat rencana penyelesaian dan dalam menyelesaikan masalah dan memeriksa kembali jawaban sudah melakukan proses asimilasi dan abstraksi. Mahasiswa dengan tipe kepribadian Artisan dan Rational dalam prosedur Polya sudah melakukan proses asimilasi dan abstraksi. Mahasiswa dengan tipe kepribadian Idealist juga melakukan proses asimilasi dan abstraksi, tetapi pada prosedur memeriksa kembali jawaban, hanya melakukan asimilasi saja.
\end{abstract}

Key Words: Profil Berpikir, Numerical Analysis, dan Tipe Kepribadian

\section{PENDAHULUAN}

Numerical Analysis merupakan mata kuliah yang diberikan pada semester VII di program studi Pendidikan Matematika IKIP PGRI Madiun. Dalam mempelajari pemecahan permasalahan Numerical Analysis ini mahasiswa harus mempelajari atau memahami mata kuliah lain sebagai prasyarat untuk menyelesaikan permasalahan yang ada pada Numerical Analysis seperti mata kuliah aljabar. Pemecahan masalah juga menjadi hal yang penting untuk ditanamkan pada diri mahasiswa. Dengan pemecahan masalah Numerical Analysis, membuat Numerical Analysis tidak kehilangan maknanya, sebab suatu konsep atau prinsip akan bermakna kalau dapat diaplikasikan dalam pemecahan masalah. Setelah disadari pentingnya pemecahan masalah Numerical Analysis dalam dunia pendidikan matematika, maka harus diusahakan agar mahasiswa mencapai hasil yang optimal dalam menguasai keterampilan pemecahan masalah. Dalam pembelajaran matematika, dalam me-nyelesaikan masalah mahasiswa biasanya melakukan proses berpikir. Menurut Sudarman (2009: 2), proses berpikir adalah aktifitas yang terjadi dalam otak manusia. Informasi dan data yang masuk diolah, sehingga data dan informasi yang sudah ada di dalam perlu penyesuaian bahkan perubahan atau proses ini sering disebut dengan adaptasi. Adaptasi terhadap skema baru dilakukan dengan dengan dua cara yaitu asimilasi dan akomodasi, tergantung jenis skema yang masuk ke dalam struktur mental. Proses asimilasi dan akomodasi akan berlangsung terus menerus sampai terjadi keseimbangan.

Keirsey dan Bates (1984: 30-66) dan Keirsey (2009) menggolongkan kepribadian menjadi empat tipe, yaitu The Guardians (The Epimethean Temperament), The Artisans 
(The Dionysian Temperament), The Rationals (The Promethean Temperament), dan The Idealists (The Apollonian Temperament). Penggolongan yang dilakukan oleh Keirsey ini berdasar pemikiran bahwa perbedaan nyata yang dapat dilihat dari seseorang adalah tingkah laku (behaviour). Tingkah laku dari seseorang merupakan cerminan hal yang nampak dari apa yang dipikirkan dan dirasakan oleh orang tersebut. Implikasi dari pernyataan ini adalah, kalau seseorang hendak mengetahui hal yang dipikirkan oleh orang lainnya, dapat dibaca melalui tingkah lakunya.

Dalam dunia pendidikan, untuk mengetahui pemikiran seorang mahasiswa mengenai pengerjaannya terhadap masalah tertentu, tentunya bukan dilihat dari tingkah lakunya, akan tetapi secara spesifik dari hasil pekerjaan mahasiswa. Untuk dapat mengetahui pemikiran seorang mahasiswa, salah satunya dapat dengan cara mengajak mahasiswa untuk berdiskusi dengan pengajar, sehingga mahasiswa mau mengatakan apa yang ada dalam pemikirannya pada saat mengerjakan masalah tertentu. Dengan menyadari perbedaan kondisi pada masing-masing mahasiswa, maka pengajar dapat memberikan metode mengajar terbaik untuk masing-masing pribadi mahasiswa. Metode mengajar akan diberikan berdasar proses berpikir yang dimiliki oleh mahasiswa, dan salah satu proses berpikir dapat diselidiki berdasar tipe kepribadian yang telah dikelompokkan berdasar pengelompokan oleh David Keirsey. Hal ini karena proses berpikir siswa dipengaruhi oleh kepribadian siswa (M. J. Dewiyani, 2008(a)). Dengan metode mengajar yang disesuaikan berdasar proses berpikirnya, maka diharapkan proses mengajar belajar dapat menyentuh mahasiswa lebih secara pribadinya, karena memang sudah seharusnya mahasiswa mempunyai hak untuk diperhatikan oleh setiap pengajar secara pribadi masing-masing, dan bukan hanya secara klasikal, dimana banyak pribadi bergabung menjadi satu.

Dengan metode mengajar yang sesuai untuk masing-masing mahasiswa, maka diharapkan segala sesuatunya akan berjalan dengan lancar. Materi akan nampak indah, tugas-tugas akan dikerjakan dengan suka hati. Tetapi jika situasi belajar tidak mendukung, maka segalanya akan nampak menjadi berat, melelahkan, dan membosankan. Walaupun sebenarnya tidak ada yang salah atau benar dari cara belajar maupun metode mengajar, karena hal itu merupakan cerminan dari masing-masing kepribadian, akan tetapi jika seorang mahasiswa masuk dalam lingkungan dengan cara belajar yang tidak sesuai dengan cara belajarnya, tentu akan sangat berpengaruh pada hasil belajarnya.

Untuk dapat mencapai hal tersebut, maka pada penelitian ini akan dilihat profil mahasiswa pendidikan matematika semester VII dalam memecahkan masalah Numerical Analysis ditinjau dari tipe kepribadian guardian, artisan, rational, dan idealist. Agar profil mahasiswa dalam memecahkan masalah Numerical Analysis dapat diketahui dengan lebih baik, maka pada penelitian ini, dalam menyelesaikan masalah matematika, mahasiswa diarahkan untuk menggunakan langkah Polya.

\section{METODE}

Penelitian ini berusaha mengungkapkan secara mendalam profil mahasiswa semester VII pendidikan matematika dalam memecahkan masalah Numerical Analysis berdasarkan penggolongan tipe kepribadian menurut Keirsey, yaitu tipe guardian, artisan, rational, dan idealist, dimana dalam memecahkan masalah mengacu pada langkah-langkah pemecahan masalah model Polya. Data yang dikumpulkan dalam penelitian ini bersifat kualitatif eksploratif, yaitu penjelasan aktual tentang bagaimana mahasiswa semester VII pendidikan matematika dalam memecahkan masalah Numerical Analysis dengan mengacu langkah-langkah Polya berdasarkan tipe kepribadiannya. 
Dalam penelitian ini data yang diperoleh berupa catatan hasil pekerjaan mahasiswa dalam memecahkan masalah Numerical Analysis berdasarkan langkah Polya secara tertulis dan transkrip hasil wawancara peneliti dengan subjek penelitian setelah subjek penelitian mengerjakan masalah matematika. Subjek penelitian ini adalah mahasiswa pendidikan matematika semester VII IKIP PGRI Madiun tahun ajaran 2015/2016. Pemilihan subjek ini karena mata kuliah Numerical Analysis diberikan pada semester VII. Adapun pemilihan subjek penelitian berdasarkan teknik pengambilan stratified sampling dan purposive sampling. Pemilihan ini berorientasi kepada pemilihan sampel dimana populasi dan tujuan yang spesifik dari penelitian diketahui oleh peneliti sejak awal (Yatim Riyanto: 67). Stratified sampling adalah metode pemilihan sampel dengan cara membagi populasi ke dalam kelompok-kelompok yang homogen yang disebut dengan strata (Sugiarto (dkk), 2001: 73). Subjek yang akan dipilih diketahui terlebih dahulu karakteristiknya, dalam hal ini mahasiswa diberi lembar tugas untuk menentukan tipe kepribadian menurut Keirsey. Dari hasil pengerjaan lembar tugas tersebut akan diperoleh kelompok-kelompok mahasiswa tipe guardian, tipe artisan, tipe rational, dan tipe idealist.

Untuk mendapatkan data penelitian, mahasiswa diminta untuk menulis dan menyampaikan apa yang dipikirkan ketika memecahkan masalah Numerical Analysis, kemudian diwawancarai. Untuk memperoleh proses berpikir tipe kepribadian mahasiswa dalam memecahkan masalah Numerical Analysis, maka dapat dilakukan dengan langkahlangkah sebagai berikut.

1. Mahasiswa diberi tugas untuk memecahkan masalah Numerical Analysis, sekaligus menuliskan dan mengungkapkan secara verbal apa yang dipikirkan saat menyelesaikan masalah tersebut

2. Peneliti mengemukakan pertanyaan hanya jika diperlukan untuk mengklarifikasi apa yang sedang dipikirkan mahasiswa.

Peneliti mengadakan wawancara berkaitan lembar jawaban pemecahan masalah yang telah dibuat oleh subjek penelitian. Karena penelitian ini adalah penelitian kualitatif, maka peneliti berperan sebagai instrumen utama dalam mengumpulkan data, yang dibantu dengan instrumen pendukung yaitu: (1) instrumen penggolongan tipe kepribadian, (2) instrumen lembar tugas menyelesaikan masalah matematika, dan (3) pedoman wawancara.

a. Instrumen Penggolongan Tipe Kepribadian

Instrumen lembar tugas pertama dalam penelitian ini adalah lembar tugas untuk menentukan penggolongan tipe kepribadian. Instrumen lembar tugas ini bertujuan untuk memperoleh data tipe kepribadian mahasiswa menurut Keirsey Instrumen ini diambil dari buku Please Understand Me karangan David Keirsey dan Marilyn Bates. Karena instrumen asli dalam bahasa Inggris, maka harus diterjemahkan terlebih dahulu ke dalam bahasa Indonesia untuk menghindarkan salah tafsir dalam bahasa. Setelah instrumen diterjemahkan, selanjutnya divalidasi oleh ahli, dalam hal ini adalah dosen bahasa inggris. Yang dimaksud ahli dalam hal ini adalah para validator yang berkompeten melakukan validasi terhadap instrumen. Validasi instrumen penggolongan tipe kepribadian diarahkan pada kesesuaian bahasa dan isi dari pertanyaan.

b. Instrumen Lembar Tugas Menyelesaikan Masalah Matematika

Instrumen lembar tugas ini bertujuan untuk mengetahui proses berpikir mahasiswa dalam memecahkan masalah Numerical Analysis yang berkaitan dengan abstraksi dan berdasar langkah-langkah penyelesaian menurut Polya. Penyusunan instrumen pemecahan masalah diawali dengan mengkaji mata kuliah Numerical Analysis yang ditetapkan dalam standar kelulusan, selanjutnya dikaji berbagai materi 
pemecahan masalah yang berkaitan dengan abstraksi yang ditetapkan satu masalah, yaitu yang berkaitan dengan permasalahan Numerical Analysis. Instrumen lembar tugas ini selanjutnya dikonsultasikan dan divalidasi oleh dua orang dan dua orang praktisi. Yang dimaksud ahli adalah dosen senior pendidikan matematika (dua orang) dan yang dimaksud praktisi adalah dosen yang pernah mengampu mata kuliah Numerical Analysis.

c. Instrumen Pedoman Wawancara

Penyusunan instrumen pedoman wawancara diawali dengan mempelajari dan mengkaji teori-teori proses berpikir yang dijadikan pedoman dalam menyusun pertanyaan. Pertanyaan-pertanyaan yang disusun didasarkan pada tujuan untuk mengetahui profil mahasiswa dalam memecahkan masalah Numerical Analysis terkait dengan abstraksi berdasarkan langkah-langkah Polya dan untuk menggali informasi proses berpikir mahasiswa yang belum atau tidak tertuang dalam lembar jawab menyelesaikan masalah matematika yang terkait dengan abstraksi berdasarkan langkah-langkah Polya. Instrumen wawancara ini memuat pertanyaan-pertanyaan dengan maksud mengungkap aktivitas profil mahasiswa ketika menyelesaikan masalah. Pedoman wawancara bersifat semi-struktur dengan tujuan menemukan masalah dengan terbuka, artinya subjek diajak mengemukakan pendapat dan ideidenya dengan penyelesaian masalah yang dibuat, mulai memahami masalah, membuat rencana penyelesaian masalah, melaksanakan perencanaan penyelesaian masalah, sampai dengan memeriksa kembali jawaban. Hal ini dilakukan karena tidak semua yang ada di dalam pikiran subjek penelitian tertuang secara tertulis pada lembar jawaban. Karena penelitian ini akan mengungkap profil mahasiswa dalam menyelesaikan masalah Numerical Analysis yang berkaitan dengan abstraksi berdasarkan langkah-langkah Polya ditinjau dari tipe kepribadian, maka peneliti tidak melakukan intervensi terhadap pemecahan masalah dari mahasiswa tersebut. Peneliti hanya memberikan kesempatan untuk refleksi kepada mahasiswa yang menjawab salah. Instrumen wawancara ini selanjutnya divalidasi oleh ahli yang terdiri atas dua orang. Yang dimaksud ahli dalam hal ini adalah dosen pendidikan matematika. Dipilihnya dosen karena dosen dipandang sebagai pakar dan praktisi yang telah ahli dan berpengalaman dalam mengembangkan instrumen penelitian. Validasi intrumen wawancara diarahkan pada kejelasan butir pertanyaan dan apakah pertanyaan sudah mengungkap profil mahasiswa dalam menyelesaikan masalah Numerical Analysis berdasarkan langkah-langkah Polya.

Proses analisis data menggunakan model Miles dan Huberman (dalam Sugiyono, 2008: 337-345) yang dilakukan dengan langkah-langkah sebagai berikut:

1. Reduksi data, yaitu kegiatan yang mengacu pada proses pemilihan dan pengidentifikasian data yang memiliki makna jika dikaitkan dengan masalah penelitian, dan selanjutnya membuat kode pada setiap satuan sehingga diketahui berasal dari sumber mana.

2. Penyajian data yang meliputi pengklasifikasia data, yaitu menuliskan kumpulan data yang terorganisir dan terkategori sehingga memungkinkan untuk menarik kesimpulan dari data tersebut. Data-data yang dikumpulkan berupa respon-respon subjek yang menunjukkan profil subjek penelitian dalam mengerjaan masalah-masalah masalah matematika yang terkait dengan abstraksi berdasaran langkah-langkah Polya.

3. Penarikan kesimpulan dengan memperhatikan hasil pengerjaan lembar tugas dalam menyelesaikan masalah matematika dan hasil wawancara untuk menemukan karakteristik-karakteristik profil subjek penelitian berdasarkan tipe kepribadiannya. 


\section{HASIL DAN PEMBAHASAN}

Subjek peneltian ini adalah mahasiswa semester VII Program Studi Matematika IKIP PGRI Madiun. Untuk mengetahui tipe kepribadian yang dikembangkan oleh Keirsey (1984:5-10), pengisian instrumen penggolongan tipe kepribadian ini dilakukan melalui situs web dengan alamat http://www.keirsey.com/ sorter/instruments2.aspx.

Pengisian istrumen ini dilakukan di lab komputer matematika yang sudah dilengkapi dengan jaringan internet. Dari hasil pengisian tersebut diperoleh hasil sebagai berikut :

Tabel 1. Tipe Kepribadian Mahasiswa Semester VII Prodi Pendidikan Matematika

\begin{tabular}{lcccccc}
\hline \multirow{2}{*}{ No } & \multirow{2}{*}{ Kelas } & \multicolumn{5}{c}{ Tipe Kepribadian } \\
\cline { 3 - 6 } & & Guardian & Artisan & Rational & Idealist & \\
\hline 1. & VII A & 28 & 2 & 2 & 3 & 35 \\
\hline 2. & VII B & 23 & 5 & 1 & 1 & 30 \\
\hline 3. & VII C & 21 & 1 & 3 & 2 & 27 \\
\hline & Jumlah & 72 & 8 & 6 & 6 & 92 \\
\hline
\end{tabular}

Dari beberapa mahasiswa tersebut dipilih satu mahasiswa dari setiap tipe kepribadian yaitu mahasiswa tipe guardian, mahasiswa tipe artisan, mahasiswa tipe rational dan mahasiswa tipe idealist. Pemilihan mahasiswa tersebut berdasarkan pertimbangan pendapat dosen pengampu mata kuliah Numerical Analysis dengan mempertimbangkan kriteria: (1) tipe kepribadian, (2) nilai indeks prestasi kumulatif, (3) keaktifan selama perkuliahan dan (4) dapat mengemukkan pendapat secara lisan maupun tulisan.

Dari masing-masing tipe kepribadian dipilih secara purposive satu mahasiswa sebagai subjek penelitian dengan cara mewancarai dosen atau pihak lain dengan mempertimbangkan kriteria berupa IPK, keaktifan selama perkuliahan dan dapat mengemukkan pendapat/ jalan pikirannya secara lisan maupun tertulis. Langkah berikutnya adalah pemberian tugas pemecahan masalah yang terdiri dari satu soal. Setelah subjek penelitian mengerjakan lembar tugas Numerical Analysis, peneliti mengadakan wawancara dengan subjek penelitian.

Sebelum menjawab soal, keempat subjek penelitian membaca soal dan dilanjutkan dengan mengidentifikasi apa yang diketahui dan apa yang ditanyakan pada soal.

1. Profil mahasiswa tipe Guardian

a. Profil mahasiswa tipe Guardian dalam memahami masalah

Mahasiswa tipe Guardian dapat menuliskan dengan lancar dan benar apa yang diketahui dan yang ditanyakan pada soal. Mahasiswa tipe Guardian dapat mengintegrasikan langsung persepsi atau pengalaman barunya ke dalam skema yang ada di pikirannya, sehingga dapat dikatakan mahasiswa tipe Guardian melakukan proses berpikir asimilasi dalam memahami masalah pada soal. Dalam memahami masalah pada soal, mahasiswa tipe Guardian melakukan proses berpikir asimilasi, dan dapat menyatakan soal dengan memisahkan hal-hal yang diketahui dan hal-hal yang ditanyakan secara eksplisit, dalam pembelajaran terhadap mahasiswa tipe guardian seorang dosen perlu membiasakan mahasiswa tipe Guardian menyatakan hal-hal yang diketahui dan ditanyakan secara eksplisit.

b. Profil mahasiswa tipe Guardian dalam merencanakan pemecahan masalah

Perencanaan yang disusun oleh mahasiswa tipe Guardian pada soal sudah cukup untuk dijadikan pedoman untuk menyelesaikan soal tersebut. Mahasiswa tipe Guardian dapat menerima informasi dari soal sehingga dapat merencanakan 
penyelesaian masalah. Mahasiswa tipe Guardian dapat mengintegrasikan langsung persepsi atau pengalaman barunya ke dalam skema yang ada dipikirannya, sehingga dapat dikatakan bahwa mahasiswa tipe Guardian melakukan proses asimilasi dengan merencanakan penyelesaian masalah. Dalam merencanakan penyelesaian masalah mahasiswa tipe Guardian melakukan proses berpikir asimilasi, dan rencana pemecahan masalah yang dibuat oleh mahasiswa tipe Guardian sudah dapat dibuat sebagai pedoman dalam memecahkan masalah.

c. Profil mahasiswa tipe Guardian dalam melaksanakan rencana

Mahasiswa tipe Guardian dapat melaksanakan perencanaan penyelesaian masalah yang disusun dengan baik dan benar, tanpa mengalami hambatan yanng berarti. Dalam hal ini mahasiswa tersebut melakukan proses asimilasi dalam melaksanakan perencanaan penyelesai-an masalah. Mahasiswa tipe Guardian dapat melaksanakan perencanaan penyelesaian masalah yang telah disusun. Mahasiswa tipe Guardian berhasil menjawab soal dengan benar tanpa mengalami hambatan yang berarti. Dalam hal ini mahasiswa tipe Guardian melakukan proses berpikir asimilasi dalam melaksanakan perencanaan penyelesaian masalah. Selain dapat berpikir asimilasi mahasiswa tipe Guardian juga berpikir abstraksi. Sehingga dapat disimpulkan mahasiswa tipe Guardian dapat melaksanakan perencanaan pemecahan masalah.

d. Profil mahasiswa tipe Guardian dalam memeriksa kembali jawaban

Mahasiswa tipe Guardian dapat memeriksa kembali jawaban dengan benar,sehingga dapat dikatakan mahasiswa tipe Guardian melakukan proses asimilasi dan abstraksi.

2. Profil mahasiswa tipe Artisan

a. Profil mahasiswa tipe Artisan dalam memahami masalah

Mahasiswa tipe Artisan belum dapat menuliskan dengan rinci apa yang diketahui dan apa yang ditanyakan pada soal. Dalam hal ini mahasiswa tipe Artisan dapat mengintegrasikan langsung persepsi atau pengalaman barunya ke dalam skema yang ada di pikirannya, sehingga dapat dikatakan mahasiswa tipe Artisan melakukan proses berpikir asimilasi dalam memahami masalah pada soal. Berdasarkan hasil wawancara dan dalam memahami masalah pada mahasiswa tipe Artisan sudah melakukan proses berpikir asimilasi dan abstraksi meskipun dalam memahami masalah tidak menuliskan secara hal-hal yang diketahui dan hal-hal yang ditanyakan secara spesifik

b. Profil mahasiswa tipe Artisan dalam merencanakan pemecahan masalah

Perencanaan yang disusun oleh mahasiswa tipe Artisan sudah dapat dipakai sebagai pedoman untuk menyelesaikan soal, sehingga mahasiswa tipe Artisan dapat mengintegrasikan langsung persepsi atau pengalaman barunya ke dalam skema yang ada di pikirannya, sehingga dapat dikatakan mahasiswa tipe Artisan melakukan proses berpikir asimilasi dalam merencanakan pemecahan masalah pada soal. Mahasiswa tipe Artisan juga melakukan proses berpikir abstraksi karena telah menggunakan simbol $\mathrm{x}$ dalam perencanaan pemecahan masalah. Berdasarkan hasil wawancara dan hasil perencanaan masalah, maka dapat disimpulkan mahasiswa tipe Artisan memiliki proses berpikir asimilasi dan abstraksi

c. Profil mahasiswa tipe Artisan dalam melaksanakan rencana mahasiswa tipe Artisan melakukan proses berpikir asimilasi dalam melaksanakan perencanaan penyele-saian masalah. Mahasiswa tipe Artisan juga melakukan proses berpikir abstraksi karena dalam pengerjakan perencanaan masalah mahasiswa tipe Artisan menggunakan simbol. Berdasarkan hasil pelaksanaan dan wawancara, mahasiswa tipe Artisan sudah melakukan proses asimilasi dan abstraksi dan 
mahasiswa tipe Artisan sudah melaksanakan langkah perencanaan masalah dengan baik dan benar.

d. Profil mahasiswa tipe Artisan dalam memeriksa kembali jawaban.

Dalam memeriksa kembali jawaban mahasiswa tipe Artisan melakukan proses berpikir abstraksi. Berdasarkan hasil pemeriksaan jawaban dan hasil wawancara, mahasiswa sudah melakukan proses berpikir abstraksi maupun asimilasi karena mahasiswa tipe Artisan saudah dapat menginterprestasikan pengalamannya persepsi atau pengalaman barunya ke dalam skema yang ada di pikirannya dan sudah menggunakan simbol-simbol.

3. Profil mahasiswa tipe Rational

a. Profil mahasiswa tipe Rational dalam memahami masalah

Mahasiswa tipe Rational belum jelas menuliskan apa yang diketahui dan apa yang ditanyakan. Mahasiswa tipe Rational melakukan proses berpikir abstraksi karena sudah bisa menginterprestasikan soal tersebut ke dalam simbol. Berdasarkan hasil wawancara dalam memahami masalah, mahasiswa tipe Rational telah melakukan proses berpikir asimilasi dan abstraksi walaupun dalam menuliskan apa yang ditanyakan mahasiswa tipe Rational belum begitu jelas, tapi dari hasil wawancara sudah diterangkan secara jelas.

b. Profil mahasiswa tipe Rational dalam merencanakan pemecahan masalah

Dalam menuliskan perencanaan penyelesaian masalah, mahasiswa tipe Rational sudah dapat menuliskan langkah-langkah tersebut tapi belum terlalu jelas. Dalam hal ini, mahasiswa tipe Rational melakukan proses berpikir asimilasi dalam perencanaan penyelesaian masalah. Berdasarkan pemecahan masalah dan hasil wawancara, mahasiswa tipe Rational sudah melakukan proses asimilasi dan abstraksi. Mahasiswa tipe Rational sudah bisa menginterprestasikan langsung persepsi atau pengalaman barunya ke dalam skema yang ada di pikirannya meskipun dalam menuangkan langkah-langkah tersebut kurang begitu spesifik

c. Profil mahasiswa tipe Rational dalam melaksanakan rencana Mahasiswa tipe Rational dapat melaksanakan perencanaan dengan baik dan benar walaupun dalam perencaan penyelesaian masalah belum terlalu jelas. Dengan demikian, mahasiswa tipe Rational dalam melaksanakan penyelesaian masalah memiliki proses berpikir asimilasi. Mahasiswa tipe Rational juga melakukan proses berpikir abstraksi karena sudah menggunakan simbol. Berdasarkan hasil pelaksanaan dan hasil wawancara, mahasiswa tipe rational sudah melakukan proses berpikir abstraksi dan asimilasi.

d. Profil mahasiswa tipe Rational dalam memeriksa kembali jawaban

Mahasiswa tipe Rational dalam memeriksa jawaban telah melakukan proses berpikir asimilasi karena dapat mengintegrasikan langsung persepsi atau pengalaman barunya ke dalam skema yang ada di pikirannya, sehingga dapat dikatakan mahasiswa tipe Rational melakukan proses berpikir asimilasi. Berdasarkan hasil pemeriksaan jawaban dan hasil wawancara, mahasiswa tipe Rational melakukan proses asimilasi dan abstraksi. Berpikir asimilasi karena mahasiswa tipe Rational sudah dapat menginterprestasikan langsung peng-alamannya barunya sesuai dengan skema yang ada dipikirannya, sedangan kan berpikir abstraksi karena sudah dapat menggunakan simbol-simbol.

4. Profil mahasiswa tipe Idealist

a. Profil mahasiswa tipe Idealist dalam memahami masalah

Mahasiswa tipe Idealist sudah dapat menuliskan apa yang diketahui dan apa yang dikatakan dengan baik dan benar walaupun belum memilih mana inti yang diketahui dan yang ditanyakan. Dalam hal ini, mahasiswa tipe Idealist dapat mengintegrasikan 
langsung persepsi atau pengalaman barunya ke dalam skema yang ada di pikirannya, sehingga dapat dikatakan mahasiswa tipe Idealist melakukan proses berpikir asimilasi dalam memahami masalah pada soal. Berdasarkan hasil memahami masalah dan hasil wawancara, mahasiswa tipe Idealist sudah melakukan proses berpikir asimilasi dan abstraksi karena mahasiswa tersebut sudah bisa menginterprestasikan langsung pengalamannya barunya ke dalam skema yang ada.

b. Profil mahasiswa tipe Idealist dalam merencanakan pemecahan masalah

Perencanaan mahasiswa tipe Idealist sudah dapat dijadikan pedoman dalam melaksanakan penyelesaian masalah walaupun kurang lengkap. Mahasiswa tipe Idealist dapat mengintegrasikan langsung persepsi atau pengalaman barunya ke dalam skema yang ada di pikirannya, sehingga dapat dikatakan mahasiswa tipe Idealist melakukan proses berpikir asimilasi dalam memahami masalah pada soal. Berdasarkan hasil perencanaan masalah dan hasil wawancara, mahasiswa tipe Idealist melakukan proses berpikir asimilasi dan abstraksi. Berpikir asimilasi karena sudah bisa menginterprestasikan langsung pengalamannya ke dalam skema yang ada dan berpikir abstraksi karena dalam wawancara sudah menggunakan simbol-simbol.

c. Profil mahasiswa tipe Idealist dalam melaksanakan rencana

Mahasiswa tipe Idealist, sudah dapat melaksanakan perencanaan masalah dengan benar tanpa ada hambatan sehingga mahasiswa tipe Idealist telah melakukan proses berpikir asimilasi. Dalam hal ini mahasiswa tipe Idealist juga telah melakukan proses abstraksi karena menggunakan simbol. Berdasarkan hasil pelaksanaan jawaban dan hasil wawancara, mahasiswa tipe Idealist sudah melakukan proses asimilasi dan abstraksi karena mahasiswa tersebut sudah dapat menginterprestasikan pengalamannya kedalam skema yang sudah ada.

d. Profil mahasiswa tipe Idealist dalam memeriksa kembali jawaban

Mahasiswa tipe Idealist dapat mengintegrasikan langsung persepsi atau pengalaman barunya ke dalam skema yang ada di pikirannya, sehingga dapat dikatakan mahasiswa tipe Idealist melakukan proses berpikir asimilasi dalam memahami masalah pada soal. Berdasarkan hasil memeriksa jwaban dan hasil wawancara, mahasiswa tipe Idealist melakukan proses berpikir asimilasi.

Tabel 2. Proses berpikir mahasiswa ditinjau dari tipe kepribadian

\begin{tabular}{ccccc}
\hline \multirow{2}{*}{$\begin{array}{c}\text { Tipe } \\
\text { Kepribadian }\end{array}$} & $\begin{array}{c}\text { Memahami } \\
\text { Masalah }\end{array}$ & $\begin{array}{c}\text { Membuat } \\
\text { Rencana } \\
\text { Penyelesaian }\end{array}$ & $\begin{array}{c}\text { Menyelesaikan } \\
\text { Masalah }\end{array}$ & $\begin{array}{c}\text { Memeriksa } \\
\text { Kembali } \\
\text { Jawaban }\end{array}$ \\
\hline \multirow{2}{*}{ Guardian } & Asimilasi & Asimilasi & $\begin{array}{c}\text { Asimilasi } \\
\text { Abstraksi }\end{array}$ & $\begin{array}{c}\text { Asimilasi } \\
\text { Abstraksi }\end{array}$ \\
\hline \multirow{2}{*}{ Artisan } & Asimilasi & Asimilasi & Asimilasi & Asimilasi \\
& Abstraksi & Abstraksi & Abstraksi & Abstraksi \\
\hline \multirow{2}{*}{ Rational } & Asimilasi & Asimilasi & Asimilasi & Asimilasi \\
& Abstraksi & Abstraksi & Abstraksi & Abstraksi \\
\hline \multirow{2}{*}{ Idealist } & Asimilasi & Asimilasi & Asimilasi & Asimilasi \\
\hline & Abstraksi & Abstraksi & Abstraksi &
\end{tabular}

\section{PENUTUP}

1. Untuk mahasiswa tipe Guardian

a. Dalam memahami masalah, melakukan proses asimilasi tetapi tidak menuliskan syarat cukup dan perlu secara eksplisit. 
b. Dalam membuat perencanaan masalah, melakukan proses berpikir asimilasi dan perencanaan masalah sudah bisa dijadikan pedoman dalam menyelesaikan masalah Numerical Analysis terutama dalam materi deret Mclaurin.

c. Dalam melaksanakan perencanaan masalah, melakukan proses berpikir asimilasi dan abstraksi, dapat menyelesaikan masalah sesuai dengan perencanaan masalah yang dibuat dengan baik dan benar.

d. Dalam memeriksa kembali jawaban, melakukan proses berpikir asimilasi dan abstraksi dan dapat memeriksa kembali jawaban dengan baik dan benar.

2. Untuk mahasiswa tipe Artisan

a. Dalam memahami masalah, melakukan proses asimilasi dan abstraksi, tetapi tidak menuliskan syarat cukup dan syarat perlu secara eksplisit.

b. Dalam membuat perencanaan masalah, melakukan proses berpikir asimilasi dan abstraksi, tetapi perencanaan pemecahan masalah yang dibuat tidak dapat dijadikan pedoman untuk menyelesaikan pemecahan masalah.

c. Dalam melaksanakan perencanaan masalah, melakukan proses berpikir asimilasi dan abstraksi,meskipun dalam perencanaan belum dapat dijadikan pedoman dalam menyelesaikan masalah, tetapi mahasiswa tipe Artisan dapat menyelesaikan pemecahan masalah dengan baik dan benar.

d. Dalam memeriksa kembali jawaban, melakukan proses berpikir dan abstraksi dan dapat memeriksa kembali jawaban dengan lancar dan benar.

3. Untuk mahasiswa tipe Rational

a. Dalam memahami masalah, melakukan proses berpikir asimilasi dan abstraksi tetapi tidak menuliskan syarat cukup dan syarat perlu secara eksplisit.

b. Dalam membuat perencanaan masalah, melakukan proses berpikir asimilasi dan abstraksi tetapi perencanaan masalah yang dibuat mahasiswa tipe Rational belum bisa dijadikan pedoman dalam menyelesaikan masalah.

c. Dalam melaksanakan perencanaan masalah, melakukan proses berpikir asimilasi dan abstraksi, meskipun dalam perencanaan masalah belum bisa dijadikan pedoman tetapi dalam pelaksanaan perencanaan masalah mahasiswa tipe Rational bisa menyelesaikan masalah dengan lancar dan benar.

d. Dalam memeriksa kembali jawaban, melakukan proses berpikir asimilasi dan abstraksi,dan sudah bisa memeriksa kembali jawaban dengan baik dan benar.

4. Untuk mahasiswa tipe Idealist

a. Dalam memahami masalah, melakukan proses asimilasi dan abstraksi tetapi tidak menuliskan syarat cukup dan perlu secara eksplisit.

b. Dalam membuat perencanaan masalah, melakukan proses berpikir asimilasi dan abstraksi tetapi perencanaan pemecahan masalah belum bisa dijadikan pedoman dalam menyelesaikan masalah.

c. Dalam melaksanakan perencanaan masalah, melakukan proses berpikir asimilasi dan abstraksi, meskipun dalam perencanaan masalah belum bisa dijadikan pedoman tetapi mahasiswa tipe Idealist sudah bisa melaksanakan pemecahan masalah dengan lancar dan benar.

d. Dalam memeriksa kembali jawaban, melakukan proses berpikir asimilasi dan sudah bisa memeriksa kembali jawaban dengan baik dan benar.

\section{DAFTAR PUSTAKA}

Sri Ari Widodo. 2011b. Efektivitas Pembelejaran Guru Bidang Studi Matematika Terhadap Prestasi Belajar Matematika Pada Siswa Kelas 5 Sekolah Dasar Se Kecamatan Kalasan Tahun Pelajaran 2010-2011. Hasil Penelitian. Yogjakarta. Universitas Sarjana Wijaya Taman Siswa. 
Sudarman. 2009. Proses berpikir siswa climber dalam menyelesaikan masalah matematika. Jurnal Didiktita, 7 (1), 1-9. Diunduh Dari http:// pdii.go.id/admim/jurnal/1010919.pdf

Anderson, John R. 1985. Cognitive Psychology And Its Implications. New York: W.H. Freeman And Company.

Akbar Sutawidjaja. 2009. Pembelajaran Berbasis Masalah. Makalah Disajikan pada Seminar Nasional Pendidian dan Pembelajaran Matematika di STKIP PGRI Tulungagung, Tulungagung, Tanggal 26 Maret 2009.

Baker, Bernadette. 2000. A calculus graphing schema. Journal Of Research In Mathematics Education, 31 (5), 557-578.

Bogdan, Robert C. Dan Biklen, Sari Knopp. 1992. Qualitative Research For Education: An Introduction To Theory And Methods. Boston: Allyn And Bacon.

Bogdan, Robert C. Dan Taylor, Steven J.. 1993. Introduction To Qualitative Research Methods. Terjemahan A. Khozin Afandi. Surabaya: Usaha Nasional.

Budiyono. 2003. Metodologi Penelitian Pendidikan. Surakarta: Sebelas Maret University Press.

Eggen, Paul D. Dan Kauchak, Donald P.,1996. Strategies For Teacher: Teaching Content And Thinking Skills. Boston: Allyn And Bacon.

E.T. Ruseffendi. 1980. Pengajaran Matematika Modern: Seri Kelima. Bandung:Tarsito.

Hamzah B. Uno. 2007. Model Pembelajaran: Menciptakan Proses Belajar Mengajar Yang Kreatif Dan Efektif. Jakarta: Bumi Aksara.

Herman, Hudojo. 1981. Teori Belajar Untuk Pengajaran Matematika. Jakarta: Proyek Pengembangan Pendidikan Guru Departemen Pendidikan Dan Kebudayaan.

Herman, Hudojo. 2005 (b). Kapita Selekta Pembelajaran Matematika. Malang: UM Press.

Johnsom, Elaine B.. 2002. Contextual Teaching And Learning. California: Corwin Press.

Joyce, Bruce Dan Weil, Marsha. 1980. Models Of Teaching. New Jersey: Prentice Hall.

Keirsey, David Dan Bates, Marilyn. 1985. Please Understand Me. California: Promotheus Nemesis Book Company.

Keirsey, David. 2009. About 4 Temperaments. (Online), (Http://Www.Keirsey.Com, Diakses 20 Mei 2015).

Lexy J. Moleong. 2007. Metodologi Penelitian Kualitatif. Edisi Revisi. Bandung: Remaja Rosdakarya.

M.J.. Dewiyani S.. 2008(A). Pengelompokan Siswa Berdasarkan Tipe Kepribadian Sebagai Sarana dalam Pembelajaran Pemecahan Masalah Matematika. Makalah Disajikan pada Seminar Nasional Matematika dan Pendidikan Matematika di Universitas Pendidikan Ganesha Singaraja, Singaraja, 21 Juni 2008.

Nana Syaodih Sukmadinata. 2005. Metode Penelitian Pendidikan. Bandung: Remaja Rosdakarya

Nurhadi, Burhan Yasin, dan Agus Gerrad Senduk. 2004. Pembelajaran Kontekstual Dan Pembelajarannya dalam KBK. Malang: UM Press.

Paul Suparno. 1997. Filsafat Konstruktivisme Dalam Pendidikan. Yogyakarta: Kanisius.

Paul Suparno. 2001. Teori Perkembangan Kognitif Piaget. Yogyakarta: Kanisius. 
Marpaung, Yansen. 1986. Proses Berpikir Siswa Dalam Pembentukan Konsep Algoritma Matematis. Makalah Pidato Dies Natalis XXXI IKIP Sanata Dharma Yogyakarta, 25 Oktober 1986.

Soedjadi. 1999. Kiat Pendidikan Matematika Di Indonesia. Jakarta: Direktorat Jendral Pendidikan Tinggi Departemen Pendidikan Nasional.

Slavin, Robert E.. 2008. Educational Psychology: Theory And Practice. Terjemahan Marianto Samosir. Jakarta: PT Indeks.

Solso, Robert L.. 1995. Cognitive Psychology. Needham Heights: Allyn \& Bacon.

Skemp, Richard R.. 1982. The Psychology Of Learning Mathematics. England:Penguin Book Ltd..

Sugiarto (Dkk). 2001. Teknik Sampling. Jakarta: Gramedia Pustaka Utama.

Syaifuddin Azwar. 2007. Metode Penelitian. Yogyakarta: Pustaka Pelajar.

Sugiyono. 2008. Metode Penelitian Pendidikan. Pendekatan Kuantitatif, Kualitatif, dan R\&D. Bandung: Alfabeta.

Wilson, Patricia S..(Ed). 1993 (A). Mathematical Problem Solving. National Council Of Teacher Of Mathematics. New York: Macmilan Publishing Company.

Wina Sanjaya. 2008. Kurikulum Dan Pembelajaran. Jakarta: Kencana Prenada Media Group.

Yatim Riyanto. 2007. Metodologi Penelitian Pendidikan Kualitatif dan Kuantitatif. Surabaya: Unesa University Press

Yovan P. Putra. 2008. Memori Dan Pembelajaran Efektif. Bandung: Yrama Widya.

Wilmintjie Mataheru. 2008. Karakteristik Proses Kognitif dalam Pemecahan Masalah Matematika. Makalah Disajikan pada Seminar Nasional Mahasiswa S3 Matematika di Universitas Gadjah Mada Yogyakarta, Yogyakarta, Tanggal 31 Mei 2008. 